\title{
The Relationship of Vulva Hygiene Behavior With Pruritus Vulvae Events When Menstruate in Adolescent Princess in Kalanganyar Village
}

\author{
Khusnul Nikmah*, Maghfirotun Ni’mah \\ Lamongan Islamic University, Indonesia \\ *khusnulnikmah.80@gmail.com
}

\begin{abstract}
Disorders of women during menstruation are very extensive, one of which is irritation or itching around the vulva and vaginal opening, medically called Pruritus vulvae. The purpose of this study was to determine the relationship between personal hygine behavior and the incidence of pruritus vulvae during menstruation. This study is analytical in nature because it tries to determine the incidence of Pruritus vulvae. The data were analyzed using the chi square test. The population in this study were all young women from the Kalanganyar village, Lamongan Regency. The sample in this study were 30 female teenagers in Kalanganyar Village RT 04 and RT 05. The results showed that young women who had personal hygine behavior during menstruation were not good. Most of them experienced pruritus vulvae as many as $25(85 \%)$ of respondents. The results of the chi square test showed that the value of $p=0.004$ means that there is a relationship between personal hygiene behavior and the incidence of pruritus vulvae during menstruation in young women in the village of circles. Poor personal hygiene behavior can affect the incidence of pruritus vulvae. As health workers, they should provide health education about the importance of personal hygiene during menstruation to increase knowledge and personal hygiene behavior during menstruation so as to minimize the incidence of pruritus vulvae.
\end{abstract}

Keywords : Behavior, Pruritus Vulvae, Personal Hygiene 


\section{STRADA Jurnal Ilmiah Kesehatan}

DOI: $10.30994 /$ sjik.v9i2.430

ISSN: 2252-3847 (print); 2614-350X (online)

Vol.9 No.2 November 2020 Page.1181-1185

\section{BACKGROUND}

Disorders in women during menstruation are very extensive, one of which is irritation or itching around the vulva and vaginal opening. medically called Pruritus vulvae. Often times the itching will cause him to scratch, and the repeated irritation can make him more uncomfortable and sore. Scratching marks are often seen when a doctor performs an examination. If the vaginal skin is scratched by sharp nails, or other objects, even though the surface does not appear damaged, secondary infections can occur immediately, such as acute candida infection, bacterial vaginosis and trichomoniasis. This once again made matters worse (Tony, 2011). The vulvae is an area that is very sensitive and easily infected during menstruation because germs easily enter and cause disease in the reproductive tract, disturbances in adolescents during menstruation, one of which is irritation or itching around the vulvae area called pruritus vulvae, Wolf (Tri 2012).

Pruritus vulvae usually occurs at night, this is because while sleeping, young women unwittingly scratch the area so that it can cause some bruising and bleeding. In a later stage Pruritus vulvae affects a woman's social life, Wolf (in tri 2012). This incident requires young women to take good care of their reproductive organs. This is motivated by the incidence of menstruation which is dirty blood accompanied by itching in the vulvae so that if it is not kept clean, it will have the potential for infection in the reproductive organs (Handayani, 2011).

Vulva hygiene knowledge and skills are an effort to prevent and control infection, prevent skin damage, increase comfort and maintain personal hygiene (Irianto, 2015). Vulva hygiene is done by cleaning the external genetalia area when bathing or urinating (BAK). If the implementation is not in accordance with the procedure or not even done, it will affect the vagina.

Hygienic behavior during menstruation can be done by cleaning the vagina using clean water and cleaning it from front to back (from the direction of the vagina to the anus) to prevent dirt / bacteria from entering the vagina and changing sanitary napkins as often as possible after being full or not more than 6 hours ( Kusmiran, 2012).

Based on the background description above, the researcher is interested in knowing the relationship between personal hygine behavior and the incidence of pruritus vulvae during menstruation in young women in the village of Kalanganyar.

\section{METHODS}

This research is analytic in nature because it tries to study the incidence of Pruritus vulvae. Based on time, this study used a cross sectional approach. The data were analyzed using the chi square test. Based on the place of research, including field research. The population in this study were all young women from the village of Kalanganyar, Lamongan Regency. The samples in this study were 30 female teenagers in Kalanganyar Village RT 04 and RT 05. 


\section{STRADA Jurnal Ilmiah Kesehatan}

DOI: $10.30994 /$ sjik.v9i2.430

ISSN: 2252-3847 (print); 2614-350X (online)

Vol.9 No.2 November 2020 Page.1181-1185

\section{RESULT}

The following is a table of the calculation of the research results:

Table 3.1 Personal Hygine Behavior during Menstruation in young women in the village of Kalanganyar

\begin{tabular}{clcc}
\hline No & $\begin{array}{l}\text { Personal Hygiene } \\
\text { Behavior }\end{array}$ & Frequency Persentage (\%) \\
\hline $\mathbf{1}$ & Very Good & 1 & 3 \\
\hline $\mathbf{2}$ & Good & 4 & 13 \\
\hline $\mathbf{3}$ & Not Good & 25 & 84 \\
\hline \multicolumn{2}{r}{ Total } & 30 & 100 \\
\hline
\end{tabular}

Based on table 3.1 it shows that most of the personal hygiene behaviors during menstruation in young women in the village of Kalanganyar are not good as many as 25 $(85 \%)$ of respondents.

Table 3.2 Incidence of pruritus vulvae during menstruation in adolescent girls in the village of kalanganyar

\begin{tabular}{clcc}
\hline No & Incidence of Pruritus Vulvae & Frequency & Percentage (\%) \\
\hline 1 & Do not Have Pruritus Vulvae & 5 & 15 \\
\hline 2 & Experiencing Pruritus Vulvae & 25 & 85 \\
\hline \multicolumn{2}{c}{ Total } & 30 & 100 \\
\hline
\end{tabular}

Based on Table 3.2 it shows that most of the respondents experienced pruritus vulvae as many as $25(85 \%)$ of respondents.

Table 3.3 The relationship between personal hygiene behavior and the incidence of pruritus vulvae in young women in the village of Kalanganyar

\begin{tabular}{|c|c|c|c|c|c|c|c|}
\hline \multirow{2}{*}{$\begin{array}{l}\mathrm{N} \\
\mathrm{o}\end{array}$} & \multirow{2}{*}{$\begin{array}{l}\text { Personal } \\
\text { hygiene } \\
\text { behavior }\end{array}$} & \multicolumn{4}{|c|}{ Incidence of pruritus vulvae } & \multicolumn{2}{|c|}{ Amount } \\
\hline & & $\begin{array}{l}\text { Do not } \\
\text { experience } \\
\text { pruritus } \\
\text { vulvae }\end{array}$ & & $\begin{array}{l}\text { Experiencing } \\
\text { pruritus } \\
\text { vulvae }\end{array}$ & & $\begin{array}{l}\text { Frequency } \\
\text { (N) }\end{array}$ & $\begin{array}{c}\text { Persentage } \\
(\%)\end{array}$ \\
\hline & & $\mathrm{F}$ & $\%$ & $\mathrm{~F}$ & $\%$ & & \\
\hline 1 & Very Good & 1 & 3 & 0 & 0 & 1 & 3 \\
\hline 2 & Good & 2 & 6 & 3 & 10 & 5 & 16 \\
\hline 3 & Not Good & 2 & 6 & 22 & 75 & 24 & 81 \\
\hline & Total & 5 & 15 & 25 & 85 & 30 & 100 \\
\hline & chi Square & & & $P=0$ & & & \\
\hline
\end{tabular}

Based on Table 3.3 above, it shows that young women who have bad personal hygiene during menstruation, most of them experience pruritus vulvae as many as 25 $(85 \%)$ of respondents. 


\section{STRADA Jurnal Ilmiah Kesehatan}

DOI: $10.30994 /$ sjik.v9i2.430

ISSN: 2252-3847 (print); 2614-350X (online)

Vol.9 No.2 November 2020 Page.1181-1185

The results of the chi square test showed that the value of $p=0.004$ means that there is a relationship between Personal Hygine Behavior and the incidence of Pruritus Vulvae during Menstruation in young women in the village of Kalanganyar.

\section{DISCUSSION}

Table 3.3 shows that the majority of respondents who have bad behavior and experience pruritus vulvae are $25(85 \%)$ while those who have good behavior and do not experience pruritus vulvae are as many as $5(15 \%)$. This is because the personal hygiene habits of respondents who are not good during menstruation include not changing underwear when wet, not drying the vagina after washing, cleaning the vagina from the back to the front, not shaving pubic hair after menstruation, rarely changing sanitary napkins during menstruation, wearing underwear. not cotton and wear tight clothing (jeans). Changes in good behavior are needed to improve health and prevent disease (Kusmiran, 2011).

The results showed a relationship between personal hygiene behavior and the incidence of pruritus vulvae during menstruation. The results of this study are in line with previous research conducted by Indah (2012), showing that there is a relationship between personal hygiene behavior and the incidence of pruritus vulvae during menstruation in high school students of SMAN 1 Ngimbang Lamongan. The results of this study are also in accordance with research conducted by Wulandari (2014), which shows that there is a relationship between personal hygine behavior and the incidence of pruritus vulvae in female adolescents who are menstruating. The results of this study and previous studies indicate that personal hygine behavior during menstruation is a behavior that can affect the incidence of pruritus vulvae.

\section{CONCLUSION}

The results showed: 1) Personal hygine behavior during menstruation among young women in the village of Antarayar mostly had bad behavior; 2) Most of the young women in the Parayar village experience pruritus vulvae; 3) There is a relationship between personal hygiene behavior and the incidence of pruritus vulvae during menstruation. Almost all of the respondents in this study had experienced Pruritus vulvae during menstruation.

\section{REFERENCES}

Bohl, T.G. 2005. Overview of vulvar pruritus through the life cycle. Clinical American Journal of Obstetrics \& Gynecology. 786-807.

Diyanti, 2014. Hubungan Antara Pengetahuan dan Perilaku tentang Vulva Hygiene dengan Kejadian Pruritus Vulvae saat Menstruasi pada Pelajar Putri SMA Negeri 1 Kartasura.

Handayani, H. 2011. Hubungan Pengetahuan, Sikap, dan Perilaku Remaja Putri tentang Kebersihan Organ Genetalia Eksterna di Madrasah Tsanawiyah Pembangunan. Program Studi Pendidikan Dokter Fakultas Kedokteran dan Ilmu Kesehatan Universitas Islam Negeri Syarif Hidayatullah, Jakarta.

Indah. (2012). Kejadian Pruritus Vulvae Saat Menstruasi pada Remaja Putri (Studi pada Siswi SMAN 1 Ngimbang Kabupaten Lamongan. Surabaya: Universitas Airlangga.

Intan Kumalasari, Irwan Andhyantoro, Kesehatan Reproduksi "Untuk Mahasiswa Kebidanan dan Keperawatan”. (Jakarta:Salemba Medika,2012). 


\section{STRADA Jurnal Ilmiah Kesehatan}

DOI: $10.30994 /$ sjik.v9i2.430

ISSN: 2252-3847 (print); 2614-350X (online)

Vol.9 No.2 November 2020 Page.1181-1185

Irianto, K. 2015. Kesehatan reproduksi (Reproduvtive Health) teori dan praktikum. ALFABETA:Bandung.

Kusmiran.(2012). Kesehatan Reproduksi Remaja dan Wanita. Jakarta: Salemba Medika

Tony, Djajakusumah. 2011. Penatalaksanaan Pruritus Anogenital. Surabaya: 22-23

Tri, Fufut. 2012. Kejadian Pruritus Vulvae Saat Menstruasi Pada Remaja Puteri. Jurnal Unair.

Shohibat A, Mukhoirotin. 2017. Hubungan perilaku personal hygiene saat menstruasi dengan kejadian pruritus vulvae pada Santriwati di Asrama Hurun'inn Darul Ulum Jombang. Jombang: Universitas Pesantren Tinggi Darul Ulum. 